\title{
ANALISIS YURIDIS PEMAKNAAN KONSEP DALAM PASAL 16 UNDANG-UNDANG RUMAH SUSUN BAGI MASYARAKAT BERPENGHASILAN RENDAH
}

\author{
Cindy Sandra Lumingkewas \\ Politeknik Negeri Manado \\ Buha Mapanget \\ E-mail: cindy.notariat@yahoo.com
}

Diterima: 24 Agustus 2016 | Direview: 9 September 2016 | Disetujui: 10 Januari 2017

\begin{abstract}
The purpose of this research is to determine the concept of Article 16(2) of Apartment Act in favor of the LIC in terms of ownership of an apartment unit, and also the elaboration of this concept that provide convenience to the LIC. This is a normative legal research using the legislation and conceptual approach. The results is that the meaning of the concept of $20 \%$ in the provisions of Article 16(2) of the Apartment Act was the construction of general apartment at least $20 \%$ of the total floor area of commercial apartment is a legal obligation of the perpetrator development of this commercial, in which the liability asserted in Article 97 followed the criminal sanctions under Article 109. 20\% should be interpreted according to the political law and balanced composition between the number of simple, medium and luxury homes (3: 2: 1). More detailed settings of Article 16(2) of Apartment Act are necessary because it takes certain assertions, among others: a. Executive Agency affirmation by government formation, incentives given to construction of general apartment actors, and to provide support and services to the ownership of the apartment unit for the LIC; $b$. affirmation of the maximum limit for the commencement and completion of construction of general apartment as the implementation of the obligations of Article 16 (2); and, c. LIC classification affirmation made by Government Regulation.
\end{abstract}

Key words: apartment, low-income people

\section{Abstrak}

Tujuan penelitian ini adalah untuk mengetahui dan menganalisis makna konsep Pasal 16 ayat (2) UU Rumah Susun tentang kewajiban menyediakan rumah susun umum sekurang-kurangnya $20 \%$ (dua puluh persen) dari total luas lantai rumah susun komersial, dan bagaimana penjabaran konsep pasal 16 (2) UU Rumah Susun yang memberi kemudahan bagi MBR. Penelitian hukum normatif ini dengan menggunakan pendekatan peraturan perundang-undangan dan pendekatan konseptual. Hasil penelitiannya adalah bahwa makna konsep 20\% dari ketentuan Pasal 16 ayat (2) UU Rumah Susun yaitu pembangunan rumah susun umum sekurangnya-kurangnya $20 \%$ dari total luas lantai rumah susun komersial yang dibangun merupakan kewajiban hukum dari pelaku pembangunan rumah susun komersial, di mana kewajiban ini dipertegas dalam Pasal 97 yang diikuti ancaman pidana dalam Pasal 109 Pengertian 20\% itu seharusnya ditafsirkan menurut politik hukum tentang komposisi jumlah rumah yang berimbang antara rumah rumah sederhana, rumah menengah, dan rumah mewah $(3: 2: 1)$. Penjabaran konsep Pasal 16 ayat (2) Undang-undang Rumah Susun diperlukan karena dibutuhkan penegasan-penegasan tertentu, antara lain: a. penegasan pembentukan Badan Pelaksana oleh pemerintah, pemberian insentif kepada pelaku pembangunan rumah susun serta memberikan bantuan dan kemudahan untuk 
pemilikan sarusun bagi MBR; b. penegasan tentang jangka waktu dan selesainya pembangunan rumah susun umum sebagai pelaksanaan kewajiban dari Pasal 16 ayat (2) Undang-undang Rumah Susun; dan, c. penegasan klasifikasi MBR dilakukan melalui Peraturan Pemerintah.

Kata kunci: rumah susun, masyarakat berpenghasilan rendah

\section{Latar Belakang}

Keuntungan dari pembangunan rumah susun dikemukakan oleh Imam Koeswahyono ${ }^{1}$ dengan uraian bahwa apabila pembangunan kota-kota tersebut dibiarkan berkembang secara horizontal, maka menghabiskan tanahtanah pertanian yang subur di kawasan kotakota tadi. Di samping itu, pembangunan kota secara horizontal akan membawa akibat biaya pembangunan dan pemeliharaan prasarana dan utilitas kota yang lebih mahal. Masyarakat kota akan menanggung beban ongkos transportasi yang lebih tinggi dan hilangnya waktu di perjalanan menjadi lebih banyak. Intensitas transportasi bagi para pekerja atau pegawai akan meningkat, sehingga akan meningkatkan kemacetan lalu lintas yang akan membuat kota terasa menjadi lebih mahal bagi penghuni. Salah satu upaya untuk mengurangi permasalahan tersebut adalah dengan pembangunan rumah-rumah susun yang manfaatnya akan dapat mengurangi penggunaan tanah dan mendekatkan penghuni ke daerah tempat kerjanya, memperpendek jaringan prasarana dan utilitas kota dan membuat ruang-ruang terbuka kota yang lebih lega dan nyaman.

Berbagai keuntungan yang dapat diperoleh dari pembangunan rumah-rumah susun tersebut telah mendorong tumbuh dan berkembangnya pembangunan rumah susun di Indonesia. Kenyataan tentang adanya pembangunan rumah susun di Indonesia telah membawa akibat bagi Pemerintah Indonesia untuk merubah paradigma bahwa pembangunan rumah susun merupakan suatu hal penting bagi pembangunan sehingga pemerintah membentuk undang-undang yang secara khusus mengatur tentang rumah susun pada tahun 1985 dan perubahannya pada tahun 2011.

Menurut Undang-undang tentang Rumah Susun, baik undang-undang lama maupun undang-undang yang baru, tujuan pembangunan rumah susun diutamakan kepada Masyarakat Berpenghasilan Rendah (selanjutnya disebut MBR). Pada Pasal 3 ayat (1) huruf a UU No. 16 Tahun 1985 tentang Rumah Susun, mengatur bahwa pembangunan rumah susun itu memiliki tujuan memenuhi kebutuhan perumahan yang layak bagi rakyat, terutama golongan masyarakat yang berpenghasilan rendah; sedangkan Pasal 3 huruf e Undang-undang Nomor 20 Tahun 2011 tentang Rumah Susun, menentukan bahwa penyelenggaraan rumah susun bertujuan memenuhi kebutuhan perumahan dan permukiman yang layak, terutama bagi

1 Imam Koeswahyono, Hukum Rumah Susun. Suatu Bekal Pengantar Pemahaman, (Malang: Bayumedia Publishing, 2004), hlm. 3. 
MBR. Pembangunan rumah susun memang memiliki keberpihakan kepada MBR sebagaimana antara lain ditegaskan dalam bagian Penjelasan Umum alinea 5 UU No. 20 Tahun 2011 bahwa pengaturan dalam undangundang ini menunjukkan keberpihakan negara dalam memenuhi kebutuhan tempat tinggal yang terjangkau bagi MBR. Siapa yang dimaksudkan dengan MBR didefinisikan dalam Pasal 1 angka 14 UU No. 20 Tahun 2011 tentang Rumah Susun yang menentukan bahwa masyarakat berpenghasilan rendah adalah masyarakat yang mempunyai keterbatasan daya beli sehingga perlu mendapat dukungan pemerintah untuk memperoleh satuan rumah susun (selanjutnya disebut sarusun) umum.

Suatu ketentuan yang berkenaan dengan MBR yang merupakan hal baru dalam UU No. 20 Tahun 2011 tentang Rumah Susun, yaitu ketentuan sebagaimana yang termuat dalam Pasal 16. Pasal 16 ini mengandung ketentuan sebagai berikut: 1. Pembangunan rumah susun komersial dapat dilaksanakan oleh setiap orang (Pasal 16 ayat (1)). 2. Pelaku pembangunan rumah susun komersial wajib menyediakan rumah susun umum minimal $20 \%$ dari total luas lantai rumah susun komersial yang dibangun (Pasal 16 ayat (2)). 3. Kewajiban menyediakan rumah susun sekurang-kurangnya $20 \%$ itu dapat dilakukan di luar lokasi kawasan rumah susun komersial pada kabupaten/kota yang sama (Pasal 16 ayat (3)). 4. Ketentuan lebih lanjut mengenai kewajiban menyediakan rumah susun umum sebagaimana dimaksud pada Pasal 16 ayat (2) dan ayat (3) diatur dalam peraturan pemerintah (Pasal 16 ayat (4)).

Rumusan Pasal 16 Undang-undang Rumah Susun ini menimbulkan pertanyaan, pertama-tama, tentang makna hukum, yaitu pengertian normatif ${ }^{2}$ dan konsekuensikonsekuensi hukum, dari Pasal 16 Undangundang Rumah Susun dalam keberpihakan kepada MBR dalam pembangunan rumah susun, khususnya rumah susun umum. Dalam tahap pembangunan, pertanyaan yang muncul berkenaan dengan Pasal 16 ini, antara lain yaitu apakah hitungan 20\% (dua puluh persen) dalam Pasal 16 itu berkaitan 20\% (dua puluh persen) luasan lantainya ataukah prosentasi nilai yang ekuivalen dengan $20 \%$ (dua puluh persen) luas lantai rumah susun komersial. Penelitian ini akan memberikan pemaknaan secara mendalam mengenai konsep 20\% (dua puluh persen) yang diatur di dalam Pasal 16 Undang-undang Rumah Susun yang bertujuan untuk menyediakan tempat tinggal bagi semua penduduk Indonesia. Selain itu, makna Pasal 16 ini tidak hanya terbatas pada pembangunan rumah susun saja melainkan menjangkau hal yang lebih jauh lagi yaitu sampai pada penguasaan suatu sarusun pada rumah susun

2 N.E. Algra dan K. van Duyvendijk, Mula Hukum, terjemahan J.C.T. Simorangkir dari Rechtsaanvang, (Jakarta: Binacipta, 1983), hlm. 323: "Kaidah (atau norma) berasal dari bahasa Latin = siku-siku. Suatu sikusiku mempunyai dua fungsi: a. alat pembantu untuk mengkonstruksi sudut 90 derajat; b. alat yang dapat dipergunakan untuk memeriksa apakah suatu sudut yang telah ada betul-betul 90 derajat. Kedua fungsi tersebut kita temukan kembali dalam kaidah hukum atau norma hukum". 
umum oleh MBR. Pertanyaan lainnya, antara lain, berkenaan dengan penjabaran konsep Pasal 16 Undang-undang Rumah Susun yang memberi kemudahan bagi Masyarakat Berpenghasilan Rendah. Hal ini diperlukan karena masyarakat memerlukan jaminan yang lebih rinci dan kuat tentang kemudahan memperoleh suatu satuan rusunami.

Konsep ketentuan Pasal 16 Undangundang Rumah Susun tentang kewajiban menyediakan rumah susun umum sekurangkurangnya $20 \%$ (dua puluh persen) dari total luas lantai rumah susun komersial, dan bagaimana penjabaran konsep Pasal 16 ayat (2) UU Rumah Susun yang memberi kemudahan bagi MBR.

Penelitian ini merupakan suatu penelitian hukum (legal research), khususnya penelitian hukum normatif. Pendekatan yang digunakan dalam penelitian ini yaitu pendekatan peraturan perundang-undangan (statute approach) dan pendekatan konseptual (conceptual approach). Pendekatan peraturan perundang-undangan adalah pendekatan dengan menggunakan legislasi dan regulasi, ${ }^{3}$ sedangkan pendekatan konseptual dilakukan di mana peneliti tidak beranjak dari aturan yang ada. ${ }^{4}$

\section{Pembahasan}

\section{A. Pemaknaan Konsep Dalam Ketentuan Pasal 16 Undang-}

undang Rumah Susun tentang Kewajiban Menyediakan Rumah Susun Umum sekurangkurangnya $20 \quad \% \quad$ (duapuluh persen) dari Total Luas Lantai Rumah Susun Komersial

UU No. 20 Tahun 2011 tentang Rumah Susun, pada Pasal 16 yang di dalamnya mengatur ketentuan yang tidak diatur oleh Undang-Undang Rumah Susun yang berlaku sebelumnya, yaitu UU No. 16 Tahun 1985 tentang Rumah Susun . Ketentuan pokok yang terdapat dalam Pasal 16 ayat (2) yang menentukan bahwa pelaku pembangunan rumah susun komersial wajib menyediakan rumah susun umum sekurang-kurangnya 20\% (dua puluh persen) dari total luas lantai rumah susun komesial yang dibangun. Di sini dianut konsep minimal 20\% (dua puluh persen), yaitu minimal 20\% (dua puluh persen) untuk rumah susun umum dari setiap satu rumah susun komersial, atau dengan rumusan lebih lengkap, pelaku pembangunan rumah susun komersial wajib menyediakan rumah susun umum minimal 20\% (dua puluh persen) dari total luas lantai rumah susun komersial yang dibangun.

Bagian ini membahas tentang bagaimana makna konsep ketentuan Pasal 16 UU No. 20 Tahun 2011 tentang Rumah Susun yang berpihak kepada MBR dalam hal kepemilikan rumah susun. Pasal 16 itu sendiri sebenarnya baru mengatur mengenai tahap pembangunan

3 Peter Mahmud Marzuki, Penelitian Hukum, (Jakarta: Prenada Media Group, 2011), hlm. 97.

4 Ibid., hlm. 137. 
rumah susun. Pasal 16 ayat (2) secara tersurat (eksplisit) mengatur tentang menyediakan rumah susun umum. Tetapi, keberpihakan kepada MBR belum sepenuhnya terwujud jika pembicaraan hanya sampai pada tahap menyediakan rumah susun saja. Keberpihakan kepada MBR nanti terwujud sepenuhnya jika Pasal 16 itu ditarik konsekuensinya sampai pada penguasaan sarusun oleh MBR, khususnya dengan cara dimiliki oleh MBR. Penguasaan sarusun umum, menurut Pasal 45 ayat (1) dapat dilakukan dengan cara dimiliki atau disewa. Pembahasan akan dilakukan sampai pada konsekuensi dari Pasal 16 Undang-undang Rumah Susun berkenaan dengan penguasaan suatu sarusun umum (sarusunami) oleh MBR, sebagai langkah keberpihakan pemerintah kepada MBR.

Ketentuan pokok dari Pasal 16 Undangundang Rumah Susun terdapat dalam ayat (2) dan ayat (3). Ayat (1) dari Pasal 16 sebenarnya merupakan suatu ketentuan yang tidak berkenaan dengan MBR, melainkan mengenai pelaku pembangunan rumah susun komersial. Ayat (4) dari Pasal 16 hanya mengatakan bahwa ketentuan lebih lanjut mengenai kewajiban menyediakan rumah susun umum sebagaimana dimaksudkan pada ayat (2) dan ayat (3) diatur dalam peraturan pemerintah.

Kajian mengenai makna hukum berarti ayat (2) dan ayat (3) dari Pasal 16 Undang- undang Rumah Susun, dikaji dari aspek normatif. Suatu kajian makna hukum atau dari aspek normatif, menurut Komisi Yudisial merupakan kajian dari sudut unsur-unsur norma, yaitu unsur-unsur yang berupa: (a) subjek hukum yang menjadi sasaran norma (normadressaat); (b) modus perilaku, yakni sifat-sifat norma tersebut (modus van behoren); (c) objek norma, yakni perilaku yang diminta untuk dikerjakan atau tidak dikerjakan (normgedrag); dan (d) kondisi norma, yakni persyaratan yang menyertai pelaku atau perilaku itu (Normcondities). ${ }^{5}$

Unsur-unsur norma dalam ayat (2) dan ayat (3) Pasal 16 Undang-undang Rumah Susun adalah sebagai berikut:

\section{Subjek hukum yang menjadi sasaran norma (normadressaat)}

Subjek hukum yang menjadi sasaran norma (normadressaat), sebagaimana yang tercantum dalam Pasal 16 ayat (2), adalah pelaku pembangunan rumah susun komersial. Pelaku pembangunan rumah susun pada umumnya, untuk keseluruhan yang mencakup semua macam rumah susun, menurut Urip Santoso ${ }^{6}$ yaitu:

1) Perorangan warga negara Indonesia;

2) Perorangan orang asing yang berkedudukan di Indonesia;

3) Badan usaha swasta yang berbentuk Perseroan Terbatas (PT);

5 Komisi Yudisial Republik Indonesia, Bahan Bacaan Klinik Etik dan Hukum, Buku I Materi Hukum, (Jakarta: Komisi Yudisial, 2015), hlm. 15.

6 Urip Santoso, Hukum Perumahan, (Jakarta: Kencana Prenadamedia Group, 2014), hlm. 413 - 414. 
4) Badan Usaha Milik Negara yang berbentuk Perusahaan Umum Pembangunan Perumahan Nasional (Perum Perumnas);

5) Pemerintah Provinsi, Pemerintah Kabupaten/Kota;

6) Lembaga Negara, Kementerian, Lembaga Pemerintah Non-Kementerian, Badan Otoritas.

Khususnya untuk pelaku pembangunan rumah susun komersial yaitu setiap orang (Pasal 16 ayat (1)), di mana pengertian setiap orang adalah orang perseorangan atau badan hukum (Pasal 1 angka 16 Undang-undang Rumah Susun).

\section{Modus perilaku, yakni sifat- sifat norma tersebut (modus van behoren) Modus perilaku mencakup sifat-sifat norma, yaitu perintah, larangan, izin, dan dispensasi. $^{7}$}

Sifat norma dalam Pasal 16 ayat (2) Undang-Undang Rumah Susun adalah sebagai perintah. Hal ini karena ketentuan tersebut memerintahkan orang berbuat sesuatu, yaitu pelaku pembangunan rumah susun komersial (subjek hukum yang menjadi sasaran norma) wajib menyediakan rumah susun umum sekurang-kurangnya $20 \%$ dari total luas lantai rumah susun komersial yang dibangun.

Sifat sebagai perintah dari norma dalam Pasal 16 UU No. 20 Tahun 2011 tentang
Rumah Susun ini benar-benar mendapat perhatian dari pembentuk undang-undang ini, sehingga dalam Pasal 97 diberikan ketentuan bahwa setiap pelaku pembangunan rumah susun komersial dilarang mengingkari kewajibannya untuk menyediakan rumah susun umum sekurang-kurangnya 20\% (dua puluh persen) dari total luas lantai rumah susun komersial yang dibangun sebagaimana dimaksud dalam Pasal 16 ayat (2). Untuk mempertegas norma bersifat perintah dan beban kewajiban tersebut, Pasal 109 menentukan adanya ancaman pidana dengan ketentuan bahwa setiap pelaku pembangunan rumah susun komersial yang mengingkari kewajibannya untuk menyediakan rumah susun umum sekurang-kurangnya 20\% (dua puluh persen) dari total luas lantai rumah susun komersial yang dibangun sebagaimana dimaksud dalam Pasal 97 dipidana dengan pidana penjara paling lama 2 (dua) tahun atau denda paling banyak Rp. 20.000.000.000,00 (dua puluh miliar rupiah).

Pasal 97 dan Pasal 109 Undang-undang Rumah Susun mempertegaskan hal tidak adanya dasar yang sah untuk melakukan penyampingan (derogation) terhadap Pasal 16 ayat (2) Undang-undang Rumah Susun. Pasal 16 ayat (2) Undang-undang Rumah Susun mengandung perintah yang mutlak harus dilaksanakan oleh setiap pelaku pembangunan rumah susun komersial. 


\section{Objek norma, yakni perilaku yang diminta untuk dikerjakan atau tidak dikerjakan (normgedrag)}

Objek norma terdapat dalam rumusan Pasal 16 ayat (2), yaitu dalam frasa "menyediakan rumah susun umum sekurang-kurangnya $20 \%$ (dua puluh persen) dari total luas lantai rumah susun komersial yang dibangun". Frasa ini merupakan perilaku yang diminta untuk dikerjakan.

Rumusan Pasal 16 ayat (2) dapat menimbulkan pertanyaan, apakah rumah susun umum yang akan dibangun itu luas lantainya yang sekurang-kurangnya 20\% dari total luas lantai rumah susun komersial yang dibangun, ataukah dana pembangunannya yang sekurang-kurangnya $20 \%$ dari total luas rumah susun komersial yang dibangun. Hal ini karena Pasal 16 ayat (2) tidak secara tegas menyatakan misalnya dengan rumusan menyediakan rumah susun umum dengan luas lantai sekurang-kurangnya $20 \%$ dari total luas rumah susun komersial yang dibangun.

Sehubungan dengan itu perlu diperhatikan Peraturan Menteri Perumahan Rakyat Nomor 10 Tahun 2012 tentang Penyelenggaraan Perumahan dan Kawasan Pemukiman Dengan Hunian Berimbang. Pasal 9 memberikan ketentuan:

(1) Komposisi jumlah rumah merupakan perbandingan jumlah rumah sederhana, jumlah rumah menengah, dan jumlah rumah mewah.
(2) Perbandinganjumlah rumah sebagaimana dimaksud pada ayat (1) sekurangkurangnya 3:2:1 (tiga berbanding dua berbanding satu), yaitu 3 (tiga) atau lebih rumah sederhana berbanding 2 (dua) rumah menengah berbanding 1 (satu) rumah mewah.

(3) Dalam hal tidak dapat dibangun rumah sederhana sebagaimana dimaksud pada ayat (2) dalam bentuk rumah tunggal atau rumah deret dapat dibangun dalam bentuk rumah susun umum. ${ }^{8}$

Dalam Peraturan Menteri ini terkandung suatu politik hukum berkenaan dengan pembangunan rumah dan rumah susun umum; di mana politik hukum, menurut Soedarto adalah "kebijakan dari negara melalui badan-badan negara yang berwenang untuk menetapkan peraturan-peraturan yang dikehendaki, yang diperkirakan akan digunakan untuk mengekspresikan apa yang terkandung dalammasyarakat dan untuk mencapai apa yang dicita-citakan". 9 Dalam peraturan ini tampak adanya suatu politik hukum pemerintah yang menghendaki komposisi jumlah rumah yang berimbang dengan perbandingan $3: 2: 1$, yaitu 3 atau lebih rumah sederhana berbanding 2 rumah menengah berbanding 1 rumah mewah. Hal ini dimaksudkan agar masyarakat berpenghasilan rendah yang jumlahnya terbanyak di Indonesia memiliki peluang cukup besar untuk memiliki rumah karena ketersediaan rumah (atau unit rumah susun) yang lebih banyak.

8 Pasal 9 Peraturan Menteri Perumahan Rakyat Nomor 10 Tahun 2012 tentang Penyelenggaraan Perumahan dan Kawasan Pemukiman Dengan Hunian Berimbang.

9 Ahmad Muliadi, Politik Hukum, Cetakan Ke-2, (Padang: Akademia Permata, 2014), hlm. 2. 
Berdasarkan politik hukum yang terkandung dalam Permenpera Nomor 10 Tahun 2012 tentang Penyelenggaraan Perumahan dan Kawasan Pemukiman Dengan Hunian Berimbang, menghendaki pembangunan jumlah rumah sederhana lebih banyak jumlahnya daripada rumah menengah dan mewah, maka Pasal 16 ayat (2) UndangUndang Rumah Susun juga perlu dilihat dari sudut politik hukum ini. Dengan demikian, luas lantai untuk unit rumah susun umum yang lebih banyak seharusnya menjadi menjadi perhatian utama, sehingga ketentuan 20\% itu seharusnya diartikan sebagai kewajiban untuk menyediakan rumah susun umum yang luas lantainya minimal 20\% dari total luas lantai rumah susun komersial yang dibangun.

Penggunaan kata-kata sekurangkurangnya (minimal) 20\% menunjukkan bahwa $20 \%$ itu merupakan jumlah yang paling sedikit. Dengan demikian, tidak dibenarnya untuk pembangunan hanya $19 \%$, $18 \%, 17 \%$ dan seterusnya dari total luas lantai rumah susun komersial. Sebaliknya, karena pembangunan rumah susun umum itu paling sedikit 20\% maka berarti pelaku pembangunan rumah susun komersial dapat membangun rumah susun umum 20\%, 21\%, $22 \%$ dan seterusnya. Tetapi yang merupakan kewajiban hukum adalah sejumlah $20 \%$, sedangkan jika dilakukan pembangunan di atas jumlah $20 \%$ itu merupakan perilaku suka rela dari pelaku pembangunan rumah susun komersial. Titik tolak dari mana dihitung jumlah minimum 20\% ini secara praktis dapat dilihat dari dokumen penentuan total luas lantai rumah susun seperti dalam rekomendasi Izin Mendirikan Bangunan (IMB).

\section{Kondisi norma, yakni persyaratan yang menyertai pelaku atau perilaku itu (Normcondities)}

Persyaratan yang menyertai perilaku disebutkan dalam Pasal 16 ayat (3) yang menyatakan bahwa kewajiban untuk menyediakan rumah susun umum sekurangkurangnya $20 \%$ dari total luas rumah susun komersial yang dibangun itu, dapat dilakukan di luar lokasi kawasan rumah susun komersial pada kabupaten/kota yang sama.

Dengan demikian, rumah susun umum yang dibangun sebagai pelaksanaan kewajiban menurut Pasal 16 ayat (2) itu tidak perlu tersambung secara fisik dengan rumah susun komersial yang dibangun, melainkan boleh di luar lokasi kawasan rumah susun komersial yang dibangun itu, asalkan masih pada kabupaten/kota yang sama. Pembangunan rumah susun umum sebagai pelaksanaan dari kewajiban menurut Pasal 16 ayat (2) itu tidak dibolehkan jika sudah berada di luar kabupaten/kota di mana dibangun rumah susun komersial itu walaupun pembangunanya masih berada pada satu propinsi yang sama.

Uraian terhadap Pasal 16 ayat (2) dan ayat (3) Undang-undang Nomor 20 Tahun 2011 tentang Rumah Susun dari aspek 4 (empat) sifat norma, menunjukkan bahwa pembangunan rumah susun umum sekurangnya-kurangnya $20 \%$ dari total luas lantai rumah susun komersial yang dibangun merupakan kewajiban hukum dari pelaku 
pembangunan rumah susun komersial, di mana kewajiban ini dipertegas dalam Pasal 97 yang diikuti ancaman pidana dalam Pasal 109. Pengertian 20\% itu seharusnya ditafsirkan menurut politik hukum tentang komposisi jumlah rumah yang berimbang antara rumah rumah sederhana, rumah menengah, dan rumah mewah $(3: 2: 1)$ sehingga seharusnya diartikan sebagai pembangunan rumah susun umum yang total luas lantainya minimal 20\% dari total luas lantai rumah susun komersial yang dibangun. Juga UU No. 20 Tahun 2011 tentang Rumah Susun tidak menentukan adanya kemungkinan pengecualian terhadap ketentuan dalam Pasal 16, sehingga merupakan kewajiban hukum yang tetap harus dilaksanakan oleh pelaku pembangunan rumah susun komersial.

\section{B. Penjabaran Konsep Pasal 16 ayat (2) Undang-undang Rumah Susun yang Memberikan Kemudahan kepada MBR}

Untuk mencapai tujuan dari UU No. 20 Tahun 2011 tentang Rumah Susun yang "menunjukkan keberpihakan negara dalam memenuhi kebutuhan tempat tinggal yang terjangkau bagi MBR" (Penjelasan Umum alinea 5), maka seharusnya keberpihakan itu bukan hanya sampai pada tahap pembangunan dan penyediaan rumah susun umum bagi MBR. Keberpihakan itu perlu dibuktikan sampai dengan penguasaan sarusun oleh MBR.

Pasal 46 ayat (1) Undang-undang Nomor 20 Tahun 2011 tentang Rumah Susun 10 Penjelasan Pasal 25 ayat (1) UU No. 20 Tahun 2011. 11 Ibid. menentukan bahwa hak kepemilikan atas sarusun merupakan hak milik atas sarusun yang bersifat perseorangan, di mana hak kepemilikan atas sarusun itu terpisah satu dengan yang lain, tetapi hak kepemilikan itu mencakup hak bersama atas bagian bersama, benda bersama, dan tanah bersama. Oleh karenanya, hak kepemilikan atas sarusun meliputi:

1) hak milik atas satuan rumah susun yang bersifat perseorangan yang terpisah;

2) bagian bersama, yaitu bagian rumah susun yang dimiliki secara tidak terpisah untuk pemakaian bersama, antara lain: fondasi, kolom, balok, dinding, lantai, atap, talang air, tangga, lift, selasar, saluran, pipa, jaringan listrik, gas, dan telekomunikasi. ${ }^{10}$

3) benda bersama, yaitu benda yang bukan merupakan bagian rumah susun tetapi dimiliki secara bersama secara untuk dipakai secara bersama, yang antara lain: ruang pertemuan, tanaman, bangunan pertamanan, bangunan sarana sosial, tempat ibadah, tempat bermain, dan tempat parkir yang terpisah atau menyatu dengan struktur bangunan rumah susun. ${ }^{11}$

4) tanah bersama, yaitu sebidang tanah yang digunakan atas dasar hak bersama secara tidak terpisah; yang di atas tanah itu berdiri rumah susun dan ditetapkan batasnya dalam persyaratan izin mendirikan bangunan.

Menurut Pasal 45 ayat (1), penguasaan sarusun pada rumah susun umum dapat 
dilakukan dengan cara dimiliki atau disewa. Keberpihakan itu perlu dibuktikan dengan dikuasainya suatu satuan rumah susun oleh MBR, terutama dalam bentuk memiliki suatu satuan rusunami oleh MBR.

Hal ini karena pemilik sarusun mempunyai hak terhadap hak milik atas sarusunnya, yaitu: ${ }^{12}$

a. menempati atau menghuni hak milik atas sarusunnya;

b. memberikan izin (persetujuan) kepada orang lain untuk menempati hak milik atas sarusunnya melalui sewa menyewa, pinjam pakai, atau sewa beli;

c. mewariskan hak milik atas sarusunnya kepada ahli warisnya;

d. menjual hak milik atas sarusunnya kepada orang lain;

e. menghibahkan hak milik atas sarusunnya kepada orang lain;

f. menukarkan hak milik atas sarusunnya dengan hak atas tanah atau hak milik atas sarusun orang lain;

g. menjual lelang hak milik atas sarusunnya;

h. menjadikan hak milik atas sarusunnya sebagai modal perusahaan;

i. menjadikan hak milik atas satuan rumah susunnya sebagai jaminan hutang dengan dibebani Hak Tanggungan.

Hak pemilik, menurut Imam Koeswahyono, pada pokoknya adalah: ${ }^{13}$

a. mempergunakan sendiri atau menyewakan sarusun kepada pihak lain; b. mempergunakan hak milik atas sarusun sebagai agunan/jaminan kredit dengan dibebani hak tanggungan misalnya hipotik jika tanahnya berstatus hak milik atau hak guna bangunan, fidusia jika tanahnya berstatus sebagai hak pakai;

c. memindahkan hak milik atas sarusun kepada pihak lain dalambentuk jual beli, tukar menukar, hibah, inbreng (pemasukan sebagai penyertaan dalam perusahaan).

Pembentuk UU No. 20 Tahun 2011 sebenarnya telah menyediakan sejumlah ketentuan dalam undang-undang ini untuk mencapai dan mendukung tujuan keberpihakan kepada MBR sampai pada kepemilikan sarusun. Paling tidak terdapat dua ketentuan yang mendukung kepemilikan sarusun, ataupun rusunami, oleh MBR, yaitu:

\section{Pembentukan badan pelaksana untuk mewujudkan penyediaan rumah susun yang layak dan terjangkau bagi MBR}

Menurut Pasal 72 ayat (1), untuk mewujudkan penyediaan rumah susun yang layak dan terjangkau bagi MBR, Pemerintah menugasi atau membentuk badan pelaksana. Badan Pelaksana ini dibentuk oleh pemerintah dan ditugaskan untuk mewujudkan penyediaan rumah susun yang layak dan terjangkau bagi MBR. Penugasan atau pembentukan badan pelaksana sebagaimana dimaksud pada ayat 
(1) bertujuan untuk (Pasal 72 ayat (2)):

a. mempercepat penyediaan rumah susun umum dan rumah susun khusus, terutama di perkotaan;

b. menjamin bahwa rumah susun umum hanya dimiliki dan dihuni oleh MBR;

c. menjamin tercapainya asas manfaat rumah susun; dan

d. melaksanakan berbagai kebijakan di bidang rumah susun umum dan rumah susun khusus.

Badan pelaksana ini mempunyai fungsi pelaksanaan pembangunan, pengalihan kepemilikan, dan distribusi rumah susun umum dan rumah susun khusus secara terkoordinasi dan terintegrasi (Pasal 72 ayat (3)).

Selanjutnya menurut Pasal 72 ayat (4), tugas dari Badan Pelaksana untuk melaksanakan fungsi sebagaimana dimaksud pada ayat (3) adalah:

a. melaksanakan pembangunan rumah susun umum dan rumah susun khusus;

b. menyelenggarakan koordinasi operasional lintas sektor, termasuk dalam penyediaan prasarana, sarana, dan utilitas umum;

c. melaksanakan peningkatan kualitas rumah susun umum dan rumah susun khusus;

d. memfasilitasi penyediaan tanah untuk pembangunan rumah susun umum dan rumah susun khusus;

e. memfasilitasi penghunian, pengalihan, pemanfaatan, serta pengelolaan rumah susun umum dan rumah susun khusus;

f. melaksanakan verifikasi pemenuhan persyaratan terhadap calon pemilik dan/ atau penghuni rumah susun umum dan rumah susun khusus; dan

g. melakukan pengembangan hubungan kerja sama di bidang rumah susun dengan berbagai instansi di dalam dan di luar negeri.

Pasal-pasal tentang Badan Pelaksana ini menunjukkan keberpihakan kepada MBR, yaitu pembentukan Badan Pelaksana itu sendiri oleh pemerintah adalah untuk mewujudkan penyediaan rumah susun yang layak dan terjangkau bagi MBR. Fungsi dari Badan Pelaksana ini, sebagaimana dirumuskan dalam Pasal 72 ayat (3), bukan hanya dalam pelaksanaan pembangunan, melainkan sampai pada pengalihan kepemilikan dan distribusi rumah susun umum dan rumah susun khusus. Kemudian, sebagai salah satu tugas dari Badan Pelaksana ini yaitu memfasilitasi penghunian, pengalihan, pemanfaatan, serta pengelolaan rumah susun umum dan rumah susun khusus (Pasal 72 ayat (4) huruf e).

Badan Pelaksana ini diadakan sebagai perangkat hukum pendukung keberpihakan negara kepada MBR untuk memenuhi kebutuhan tempat tinggal termasuk rumah susun, sehingga merupakan perangkat hukum yang saling mendukung dengan Pasal 16 untuk mewujudkan keberpihakan tersebut. Badan Pelaksana ini bertugas mulai dari tahap pembangunan sampai pada memfasilitasi penghunian, pengalihan, pemanfaatan, serta 
pengelolaan rumah susun umum dan rumah susun khusus.

\section{Pemberian insentif kepada pelaku pembangunan rumah susun umum dan rumah susun khusus serta memberikan bantuan dan} kemudahan bagi MBR

Pasal 88 ayat (1) UU No. 20 Tahun 2011 tentang Rumah Susun menentukan bahwa, Pemerintah dan/atau Pemerintah Daerah memberikan insentif kepada pelaku pembangunan rumah susun umum dan rumah susun khusus serta memberikan bantuan dan kemudahan bagi MBR. Pemberian insentif kepada pelaku pembangunan rumah susun umum dan rumah susun khusus, dikemukakan lebih lanjut dalam Pasal 88 ayat (2) di mana ditentukan bahwa insentif yang diberikan kepada pelaku pembangunan berupa:

a. fasilitasi dalam pengadaan tanah;

b. fasilitasi dalam proses sertifikasi tanah;

c. fasilitasi dalam proses perizinan;

d. fasilitas kredit konstruksi dengan suku bunga rendah;

e. insentif perpajakan sesuai dengan ketentuan peraturan perundangundangan; dan/atau

f. bantuan penyediaan prasarana, sarana, dan utilitas umum.

Bantuan dan kemudahan yang diberikan kepada MBR menurut Pasal 88 ayat (3), berupa:

a. kredit kepemilikan sarusun dengan suku bunga rendah; b. keringanan biaya sewa sarusun;

c. asuransi dan penjaminan kredit pemilikan rumah susun;

d. insentif perpajakan sesuai dengan ketentuan peraturan perundangundangan; dan/atau

e. sertifikasi sarusun.

Pasal 88 menunjukkan keberpihakan negara kepada MBR, khususnya untuk kepemilikan sarusun umum berupa rusunami, bantuan dan kemudahan itu berupa kredit kepemilikan sarusun dengan suku bunga rendah (Pasal 88 ayat (3) huruf a). Pasal 88 ini diadakan untuk mendukung keberpihakan negara kepada sampai pada kepemilikan suatu sarusun umum (rusunami).

Uraian sebelumnya menunjukkan bahwa ketentuan hukum pembentukan Badan Pelaksana (Pasal 72) dan ketentuan pemberian insentif kepada pelaku pembangunan rumah susun umum dan rumah susun khusus serta pemberian bantuan dan kemudahan kepada MBR (Pasal 88), merupakan ketentuan hukum yang saling mendukung dengan Pasal 16 untuk mewujudkan keberpihakan negara kepada MBR sampai pada kepemilikan sarusun umum.

Politik hukum yang bertujuan mewujudkan keberpihakan negara kepada MBR ini, selain merupakan ketentuan normatif-yuridis dalam pasal undang-undang, juga dapat dikaji secara teoritis dari sudut teori utilitarian Jeremy Bentham dan teori keadilan sebagai fairness dari John Rawls.

Menurut Jeremy Bentham, tujuan hukum adalah "The greatest happiness for the greatest 
number"14 (kebahagiaan sebesar-besarnya untuk jumlah orang sebanyak-banyaknya). Hal ini karena hukum seharusnya memberikan manfaat bagi manusia, yaitu meningkatkan kebahagiaan manusia. MBR merupakan golongan di mana sebagian terbesar rakyat Indonesia termasuk di sini.

Sehubungan dengan kelompok MBR ini, Direktur Jenderal Pembiayaan Perumahan Kementerian Pekerjaan Umum dan Perumahan Rakyat, Mourin Sitorus, mengemukakan hal-hal sebagai berikut,

Dari hasil kajian sementara Bank Dunia, ... hanya $20 \%$ penduduk di perkotaan yang dapat menjangkau harga rumah di pasaran. Sementara itu, sebanyak $40 \%$ rumah tangga di Indonesia tidak dapat menjangkau rumah dengan harga dasar. Hal ini menjadi kewajiban pemerintah, baik pemerintah pusat maupun pemerintah daerah dalam upaya untuk mewujudkan hak warga negara atas standar hidup yang layak, termasuk kebutuhan akan perumahan. ${ }^{15}$

Kutipan menunjukkan bahwa 40\% (empat puluh persen) rumah tangga di Indonesia tidak dapat menjangkau rumah dengan harga dasar. Menurut Aliran Utilitarianisme, hukum seharusnya meningkatkan kebahagiaan golongan masyarakat ini, dengan antara lain menyediakan peraturan-peraturan yang dapat membantu mereka yang memperoleh rumah dan/atau rumah susun umum. Hal ini antara lain diwujudkan ke dalam bentuk ketentuan normatif-yuridis dalam Pasal 16, Pasal 72, dan Pasal 88 Undang-undang Nomor 20 Tahun 2011.

Teori keadilan dari John Rawls mengemukakan bahwa keadilan terdiri atas dua asas, yaitu Asas Pertama, setiap orang memiliki hak kebebasan dasar yang sama; Asas Kedua, ketimpangan sosial-ekonomi harus ditata sedemikian rupa sehingga: (a) nilai (keuntungan) terbesar bagi mereka yang paling tidak beruntung, dan (b) semua jabatan dan kedudukan harus terbuka untuk semua orang dengan syarat yang menjamin adanya peluang yang adil bagi semua orang. ${ }^{16}$

Menurut Asas Kedua, dalam perkembangan masyarakat selalu akan terjadi ketimpangan sosial-ekonomi, sehingga untuk mencari jalan keluar dari ketimpangan ekonomi perlu dilakukan hal di mana dalam distribusi barang dan jasa oleh pemerintah perlu diberikan kemanfaatan/keuntungan yang lebih besar kepada orang yang paling tidak beruntung, dengan kata lain yang dari segi sosial-ekonomi lebih lemah. Solusi penanggulangan ketimpangan sosialekonomi berupa pemberian keuntungan (kemanfaatan) yang lebih besar untuk

14 Jeremy Bentham dalam Jeffrie G. Murphy dan Jules L. Coleman, Philosophy of Law. An Introduction to Jurisprudence, (Atlanta: Westview Press, Inc., 1990), hlm. 72.

15 Kementerian Pekerjaan Umum dan Perumahan Rakyat, "Pemda Harus Punya Data Jumlah MBR Yang Perlu Bantuan Pembiayaan Perumahan", http:/www.pu.go.id/berita/10622/Pemda-Harus-Punya-Data-JumlahMBR-Yang-Perlu-Bantuan-Pembiayaan-Perumahan, diakses 14 Mei 2016.

16 John Rawls, Teori Keadilan, terjemahan Uzair Fauzan dan Heru Prasetyo dari A Theory of Justice, (Yogyakarta: Pustaka Pelajar, 2006), hlm. 386. 
mereka yang paling tidak beruntung, sebagai salah satu perwujudan dari teori keadilan sebagai fairness, merupakan teori yang sesuai dengan ketentuan normatif-yuridis berupa keberpihakan negara kepada MBR dalam memenuhi kebutuhan tempat tinggal, termasuk rumah susun umum. Hal ini karena keberpihakan kepada MBR dalam memenuhi kebutuhan tempat tinggal merupakan bentuk pemberian manfaat/keuntungan yang lebih besar kepada orang yang paling tidak beruntung dalam masyarakat.

Ketentuan Pasal 16, juga Pasal 72 dan Pasal 88 Undang-undang Nomor 20 Tahun 2011, yang secara material telah secara jelas dan tegas menunjukkan keberpihakan negara kepada MBR dalam memenuhi kebutuhan tempat tinggal (rumah susun umum), ternyata dalam praktik belum dapat dilaksanakan secara optimal. Hal ini karena adanya ketentuan dalam Undang-Undang Rumah Susun ini agar pasal-pasal tersebut diatur lebih lanjut dalam Peraturan Pemerintah.

Banyak ketentuan dalam UU No.20 Tahun 2011 yang membutuhkan peraturan pelaksanaan. Pasal 119 UU No. 20 Tahun 2011 menentukan bahwa peraturan perundangundangan pelaksanaan yang diamanatkan dalam undang-undang ini diselesaikan paling lambat 1 (satu) tahun terhitung sejak undang-undang ini diundangkan. Dengan memperhatikan bahwa Undangundang Nomor 20 Tahun 2011 diundangkan

17 Urip Santoso, op.cit., hlm. 404.

18 Urip Santoso, loc.cit. pada tanggal 10 November 2012, berarti seharusnya semua peraturan perundangundangan pelaksanaan tersebut telah selesai paling lambat tanggal 10 November 2012. Tetapi, sampai dengan awal tahun 2016, baru peraturan pemerintah untuk melaksanakan perintah Pasal 12 Undang-undang Nomor 20 Tahun 2011 untuk ketentuan lebih lanjut tentang pembinaan yang diundangkan, yaitu berupa Peraturan Pemerintah Nomor 88 Tahun 2014 tentang Pembinaan Penyelenggaraan Perumahan dan Kawasan Pemukiman.

Undang-undang Nomor 20 Tahun 2011 tentang Rumah Susun terdiri atas 120 (seratus dua puluh) pasal yang terbagi ke dalam 19 (sembilan belas) bab, di mana sejumlah ketentuan membutuhkan peraturan pelaksanaan berupa Peraturan Pemerintah, Peraturan Menteri, dan Peraturan Daerah. ${ }^{17}$ Ketentuan-ketentuan dalam Undang-undang Nomor 20 Tahun 2011 yang membutuhkan peraturan pelaksanaan, yaitu:

Undang-undang Nomor 20 Tahun 2011 tentang Rumah Susun terdiri atas 120 (seratus dua puluh) pasal yang terbagi ke dalam 19 (sembilan belas) bab, di mana sejumlah ketentuan membutuhkan peraturan pelaksanaan berupa Peraturan Pemerintah, Peraturan Menteri, dan Peraturan Daerah. ${ }^{18}$ Ketentuan-ketentuan dalam Undang-undang Nomor 20 Tahun 2011 yang membutuhkan peraturan pelaksanaan, yaitu: 


\section{a. Peraturan Pemerintah}

1) Pasal 12: Ketentuan lebih lanjut mengenai pembinaan sebagaimana dimaksud dalam Pasal 6 diatur dalam Peraturan Pemerintah.

Pembinaan yang dimaksud yaitu pembinaan atas penyelenggaraan rumah susun, yang untuk tingkat nasional dilaksanakan oleh Menteri. Pembinaan menurut Pasal 16 meliputi: a. perencanaan, b. pengaturan, c. pengendalian, dan d. pengawasan. Menteri dalam melaksanaan pembinaan melakukan koordinasi lintas sektoral, lintas wilayah, dan lintas pemangku kepentingan, baik vertikal maupun horizontal.

2) Pasal 16 ayat (4): Ketentuan lebih lanjut mengenai kewajiban menyediakan rumah susun umum sebagaimana dimaksud pada ayat (2) dan ayat (3) diatur dalam Peraturan Pemerintah.

3) Pasal 20 ayat (5): Ketentuan lebih lanjut mengenai pendayagunaan tanah wakaf untuk rumah susun umum diatur dengan Peraturan Pemerintah.

4) Pasal 27: Ketentuan lebih lanjut mengenai pemisahan rumah susun serta gambar dan uraian sebagaimana dimaksud dalam Pasal 25 dan Pasal 26 diatur dengan Peraturan Pemerintah.

Pemisahan rumah susun yang dimaksud yaitu pemisahan rumah susun atas sarusun, bagian bersama, benda bersama, dan tanah bersama (Pasal 25 ayat (1)). Pemisahan dimaksud wajib dituangkan dalam bentuk gambar dan uraian (Pasal 26 ayat (1)). Ketentuan lebih lanjut tentang pemisahan ini yang harus diatur dalam Peraturan Pemerintah.

5) Pasal 45 ayat (7): Tata cara pelaksanaan pinjam-pakai atau sewa sebagaimana dimaksud pada ayat (2) diatur dalam Peraturan Pemerintah.

Hal yang perlu diatur lebih lanjut dalam suatu Peraturan Pemerintah ini adalah penguasaan sarusun pada rumah susun khusus dapat dilakukan dengan cara pinjam-pakai atau sewa.

6) Pasal 55 ayat (2): Ketentuan mengenai pedoman penyewaan sarusun sebagaimana dimaksud pada ayat (1) diatur dengan Peraturan Pemerintah.

Menurut Pasal 55 ayat (1), Sarusun pada rumah susun negara dapat disewa oleh perseorangan atau kelompok dengan kemudahan dari pemerintah. Hal ini yang perlu diatur lebih lanjut dalam Peraturan Pemerintah.

7) Pasal 60: Ketentuan lebih lanjut mengenai pengelolaan rumah susun, masa transisi, dan tata cara penyerahan pertama kali sebagaimana dimaksud dalam Pasal 56, Pasal 57, Pasal 58, dan Pasal 59 diatur dengan Peraturan Pemerintah.

8) Pasal 69: Ketentuan lebih lanjut mengenai peningkatan kualitas rumah susun diatur dalam Peraturan Pemerintah.

9) Pasal 71 ayat (2): Ketentuan lebih lanjut mengenai pengendalian penyelenggaraan rumah susun sebagaimana dimaksud 
pada ayat (1) diatur dengan Peraturan Pemerintah.

Menurut Pasal 71 ayat (1), pengendalian penyelenggaraan rumah susun dilakukan oleh pemerintah melalui: a. perizinan; b. pemeriksaan; dan c. penertiban. Hal ini yang menurut Pasal 71 ayat (2), perlu diatur dalam Peraturan Pemerintah.

10) Pasal 73: Ketentuan lebih lanjut mengenai penugasan atau pembentukan badan pelaksana sebagaimana dimaksud dalam Pasal 72 diatur dengan Peraturan Pemerintah.

Badan pelaksana yang dimaksud adalah badan pelaksana untuk mewujudkan penyediaan rumah susun yang layak dan terjangkau bagi MBR (Pasal 72 ayat (1)).

11) Pasal 78: Ketentuan lebih lanjut mengenai PPPSRS sebagaimana dimaksud dalam Pasal 74, Pasal 75, Pasal 76, dan Pasal 77 diatur dengan Peraturan Pemerintah.

Perhimpunan Pemilik dan Penghuni Sarurun (PPPSRS) yang merupakan badan hukum yang beranggotakan para pemilik atau penghuni sarusun, diperintahkan oleh Pasal 78 ini untuk diatur lebih lanjut dalam Peraturan Pemerintah.

12) Pasal 88 ayat (4): Ketentuan lebih lanjut mengenai bentuk dan tata cara pemberian insentif kepada pelaku pembangunan rumah susun umum dan rumah susun khusus serta bantuan dan kemudahan kepada MBR diatur dalam Peraturan Pemerintah.
13) Pasal 108 ayat (3): Ketentuan lebih lanjut mengenai sanksi administratif, tata cara, dan besaran denda administratif diatur dalam Peraturan Pemerintah.

Setiap orang yang menyelenggarakan rumah susun yang tidak memenuhi ketentuan dalam pasal-pasal tertentu yang disebutkan dalam Pasal 107 dikenai sanksi administratif. Sanksi administratif menurut Pasal 108 ayat (1) dapat berupa: a. peringatan tertulis; b. pembatasan kegiatan pembangunan dan/atau kegiatan usaha; c. penghentian sementara pada pekerjaan pelaksanaan pembangunan; $d$. penghentian sementara atau penghentian tetap pada pengelolaan rumah susun; e. pengenaan denda administratif; f. pencabutan IMB; g. pencabutan sertifikat laik fungsi; h. pencabutan SHM sarusun atau SKBG sarusun; i. perintah pembongkaran bangunan rumah susun; atau j. pencabutan izin usaha. Ketentuan dalam Pasal 108 ayat (1) ini yang perlu diatur lebih lanjut dalam Peraturan Pemerintah.

\section{b. Peraturan Menteri}

1) Pasal 14 ayat (2): Pedoman perencanaan pembangunan rumah susun diatur dengan Peraturan Menteri.

2) Pasal 32: Pedoman permohonan izin rencana fungsi dan pemanfaatan serta pengubahannya diatur dengan Peraturan Menteri.

3) Pasal 40 ayat (4): Ketentuan lebih lanjut mengenai standar pelayanan minimal prasarana, sarana, dan utilitas umum diatur dengan Peraturan Menteri. 
4) Pasal 54 ayat (5): Ketentuan mengenai kriteria dan tata cara pemberian kemudahan kepemilikan sarusun umum sebagaimana dimaksud pada ayat (1) diatur dengan Peraturan Menteri.

5) Pasal 96 ayat (6): Ketentuan lebih lanjut mengenai peran masyarakat dalam penyelenggaraan rumah susun dan forum pengembangan rumah susun sebagaimana dimaksud pada ayat (1) dan ayat (3) diatur dalam Peraturan Menteri.

\section{c. Peraturan Daerah}

Pasal 33: Ketentuan lebih lanjut mengenai permohonan izin rencana fungsi dan pemanfaatan sebagaimana dimaksud dalam Pasal 29 serta permohonan izin pengubahan rencana fungsi dan pemanfaatan sebagaimana dimaksud dalam Pasal 31 diatur dengan Peraturan Daerah.

Di bawah berlakunya Undang-undang Rumah Susun yang lama, yaitu UU No. 16 Tahun 1985, pernah dibuat suatu Peraturan Pemerintah untuk melaksakan UU No. 16 Tahun 1985, yaitu Peraturan Pemerintah Nomor 4 Tahun 1988 tentang Rumah Susun. Peraturan pemerintah ini merupakan peraturan pemerintah untuk melaksanakan ketentuanketentuan dalam UU No. 16 Tahun 1985. UU No. 16 Tahun 1985 tentang Rumah Susun dicabut dengan UU No. 20 Tahun 2011 tentang Rumah Susun, namun tidak berarti keseluruhan isi Peraturan Pemerintah ini otomatis tidak lagi berlaku. UU No. 20 Tahun 2011 yang menggantikan UU No. 16 Tahun 1985, dalam Pasal 118 huruf b memberikan ketentuan bahwa, semua peraturan perundang-undangan yang merupakan peraturan pelaksanaan dari UU No. 16 Tahun 1985 tentang Rumah Susun dinyatakan tetap berlaku sepanjang tidak bertentangan atau belum diganti dengan peraturan pelaksanaan yang baru berdasarkan Undang-Undang ini. Ketentuan-ketentuan dalam Peraturan Pemerintah Nomor 4 Tahun 1988 tentang Rumah Susun dinyatakan masih tetap berlaku, sepanjang tidak bertentangan atau belum digantikan dengan peraturan pelaksanaan yang baru berdasarkan UU No. 20 Tahun 2011.

Salah satu yang diperlukan adalah Peraturan Pemerintah untuk melaksanakan ketentuan dalam ayat (2) dan ayat (3) dari Pasal 16 sebagaimana yang diperintahkan oleh Pasal 16 ayat (4) yaitu ketentuan lebih lanjut mengenai kewajiban menyediakan rumah susun umum sebagaimana dimaksud pada ayat (2) dan ayat (3) diatur dalam Peraturan Pemerintah.

Ketentuan lebih lanjut tentang kewajiban menyediakan rumah susun umum sebagaimana dimaksud pada ayat (2) dan ayat (3) diperlukan adanya penegasan-penegasan tertentu, yaitu:

1. Rumusan Pasal 16 ayat (3) dapat menimbulkan pertanyaan, apakah rumah susun umum yang akan dibangun itu luas lantainya yang sekurang-kurangnya $20 \%$ dari total luas lantai rumah susun komersial yang dibangun, ataukah dana pembangunannya yang sekurangkurangnya $20 \%$ dari total luas rumah 
susun komersial yang dibangun. Hal ini karena Pasal 16 ayat (3) tidak secara tegas menyatakan misalnya dengan rumusan menyediakan rumah susun umum dengan luas lantai sekurang-kurangnya 20\% dari total luas rumah susun komersial yang dibangun. Walaupun ada politik hukum dalam Peraturan Menteri yang cenderung pada pengertian luas lantai rumah susun umum, tetapi hal ini memerlukan penegasan dalam Peraturan Pemerintah.

2. Perlu ada ketentuan tentang batas paling lama untuk dimulainya dan selesainya pembangunan rumah susun umum sebagai pelaksanaan kewajiban dari Pasal 16 ayat (2). Jika tidak ada ketentuan, dapat saja pembangunan rumah susun umum itu nanti dimulai 20 (duapuluh) kemudian, atau pelaku pembangunan rumah susun komersial mengajukan alasan pailit sehingga tidak dapat membangun rumah susun umum.

3. Klasifikasi MBR. Rumah susun umum yang disebutkan dalam Pasal 16 ayat (2) Undang-Undang Nomor 20 Tahun 2011 merupakan jenis rumah susun yang diperuntukkan bagi MBR sebagaimana dinyatakan dalam Pasal 1 angka 7 Undang-undang Rumah Susun ini bahwa rumah susun umum adalah rumah susun yang diselenggarakan untuk memenuhi kebutuhan rumah bagi masyarakat berpenghasilan rendah (MBR). Tentang apa yang dimaksud dengan MBR,
Undang-undang Nomor 20 Tahun 2011 dalam Pasal 1 angka 14 hanya mengarakan bahwa MBR adalah masyarakat yang mempunyai keterbatasan daya beli sehingga perlu mendapat dukungan pemerintah untuk memperoleh sarusun umum. Tetapi, definisi ini masih bersifat amat umum sehingga mendatangkan berbagai tafsiran yang memiliki rentang nilai yang amat luas.

Rentang nilai yang amat luas ini mulai dari yang amat kecil nilainya seperti yang ditunjukkan oleh Situs Perpustakaan Kementerian Pekerjaan Umum, bagian DirektoriistilahPekerjaanUmum, memberikan definisi dari MBR sebagai keluarga/rumah tangga yang mempunyai penghasilan maksimum Rp. 1,5 juta pertahun, ${ }^{19}$ dengan kata lain, MBR merupakan keluarga/rumah tangga yang berpanghasilan maksimum Rp. 125.000,-- per bulan, atau Rp. 4.167,- (empat ribu seratus enam puluh tujuh rupiah) per hari.

Dalam Pasal 6 Peraturan Menteri Perumahan Rakyat Republik Indonesia Nomor 3 Tahun 2014 Tentang Fasilitas Likuiditas Pembiayaan Perumahan Dalam Rangka Pengadaan Perumahan Melalui Kredit/ Pembiayaan Pemilikan Rumah Sejahtera, ditentukan bahwa,

(1) Kelompok Sasaran KPR Sejahtera untuk KPR Sejahtera Tapak dan KPR Sejahtera Syariah Tapak adalah MBR dengan penghasilan tetap maupun tidak tetap paling banyak Rp. 4.000.000,00 (empat juta rupiah) per bulan. 
(2) Kelompok Sasaran KPR Sejahtera untuk KPR Sejahtera Susun dan KPR Sejahtera Syariah Susun adalah MBR dengan penghasilan tetap maupun tidak tetap paling banyak Rp. 7.000.000,00 (tujuh juta rupiah) per bulan.

(3) Penghasilan sebagaimana dimaksud pada ayat (1) dan ayat (2) untuk masyarakat berpenghasilan tetap merupakan gaji/ upah pokok pemohon per bulan.

(4) Penghasilan sebagaimana dimaksud pada ayat (1) dan ayat (2) untuk masyarakat berpenghasilan tidak tetap merupakan pendapatan bersih atau upah rata-rata per bulan dalam setahun yang diterima pemohon. ${ }^{20}$

Peraturan Menteri Perumahan Rakyat Nomor 3 Tahun 2014 ini telah meningkatkan batas maksimum penghasilan MBR untuk kredit rumah susun umum, dari yang sebelumnya Rp.5.500.000,00 per bulan (dalam Peraturan menyeri Perumahan Rakyat Nomor 27 Tahun 2012) menjadi yang gaji/ upah pokok per bulan Rp.7.000.000,00 (tujuh juta rupiah).

Sebaiknya dalam peraturan pemerintah telah diatur tentang klasifikasi dari MBR ini, di mana ditetapkan penghasilan maksimum per bulan, dengan ketentuan PNS dan TNI/ Polri yang bergaji pokok demikian termasuk pula di dalamnya. Peraturan selanjutnya tentang jumlah gaji/upah pokok maksimum per bulan dapat diserahkan/didelegasikan kepada peraturan menteri yang memiliki tugas dalam bidang perumahan rakyat.

\section{Simpulan}

1. Makna konsep $20 \%$ dari ketentuan Pasal 16 ayat (2) Undang-undang Nomor 20 Tahun 2011 tentang Rumah Susun yang berpihak kepada Masyarakat Berpenghasilan Rendah (MBR) dalam hal kepemilikan rumah susun, yaitu pembangunan rumah susun umum sekurangnya-kurangnya $20 \%$ dari total luas lantai rumah susun komersial yang dibangun merupakan kewajiban hukum dari pelaku pembangunan rumah susun komersial, di mana kewajiban ini dipertegas dalam Pasal 97 yang diikuti ancaman pidana dalam Pasal 109. Pengertian $20 \%$ itu seharusnya ditafsirkan menurut politik hukum pengaturan tentang komposisi jumlah rumah yang berimbang antara rumah rumah sederhana, rumah menengah, dan rumah mewah $(3: 2: 1)$.

2. Penjabaran konsep Pasal 16 ayat (2) Undang-undang Rumah Susun diperlukan karena dibutuhkan penegasan-penegasan tertentu, antara lain:

a. penegasan tentang pembentukan Badan Pelaksana oleh Pemerintah, pemberian insentif kepada pelaku pembangunan rumah susun umum, serta memberikan bantuan dan kemudahan untuk pemilikan sarusun bagi MBR;

b. penegasan tentang batas jangka waktu

20 Peraturan Menteri Perumahan Rakyat Republik Indonesia Nomor 3 Tahun 2014 tentang Fasilitas Likuiditas Pembiayaan Perumahan Dalam Rangka Pengadaan Perumahan Melalui Kredit/Pembiayaan Pemilikan Rumah Sejahtera. 
dan selesainya pembangunan rumah susun umum sebagai pelaksanaan kewajiban dari Pasal 16 ayat (2)
Undang-undang Rumah Susun;

c. penegasan klasifikasi MBR dilakukan melalui Peraturan Pemerintah.

\section{DAFTAR PUSTAKA}

\section{Buku}

Algra, N.E. dan K. van Duyvendijk. Mula Hukum. Terjemahan J.C.T. Simorangkir dari Rechtsaanvang. Jakarta: Binacipta, 1983.

Komisi Yudisial Republik Indonesia. Bahan Bacaan Klinik Etik dan Hukum, Buku I Materi Hukum. Jakarta: Komisi Yudisial, 2015.

Koeswahyono, Imam. Hukum Rumah Susun. Suatu Bekal Pengantar Pemahaman. Malang: Bayumedia Publishing, 2004.

Marzuki, Peter Mahmud. Penelitian Hukum. Jakarta: Prenada Media Group, 2011.

Muliadi, Ahmad. Politik Hukum. Cetakan Ke-2. Padang: Akademia Permata, 2014.

Murphy, Jeffrie G. dan Jules L. Coleman. Philosophy of Law. An Introduction to Jurisprudence. Atlanta: Westview Press, Inc., 1990.

Rasjidi, Lili. Dasar-dasar Filsafat Hukum. Bandung: Alumni, 1982.

Rawls, John. Teori Keadilan. Terjemahan Uzair Fauzan dan Heru Prasetyo dari A
Theory of Justice. Yogyakarta: Pustaka Pelajar, 2006.

Santoso, Urip. Hukum Perumahan. Jakarta: Kencana Prenadamedia Group, 2014.

\section{Peraturan Perundang-undangan}

Undang-undang Nomor 16 Tahun 1985 tentang Rumah Susun.

Undang-undang Nomor 12 Tahun 2011 tentang Pembentukan Peraturan Perundang-undangan.

Undang-undang Nomor 20 Tahun 2011 tentang Rumah Susun.

Peraturan Pemerintah Nomor 4 Tahun 1988 tentang Rumah Susun.

Peraturan Pemerintah Nomor 88 Tahun 2014 tentang Pembinaan Penyelenggaraan Perumahan dan Kawasan Permukiman.

Peraturan Menteri Perumahan Rakyat Nomor 10 Tahun 2012 tentang Penyelenggaraan Perumahan dan Kawasan Pemukiman Dengan Hunian Berimbang.

Peraturan Menteri Perumahan Rakyat Republik Indonesia Nomor 3 Tahun 2014 tentang Fasilitas Likuiditas Pembiayaan Perumahan Dalam 
Rangka Pengadaan Perumahan Kementerian Pekerjaan Umum dan Perumahan

Melalui Kredit/Pembiayaan Pemilikan Rumah Sejahtera.

\section{Naskah Internet}

Bentham, Jeremy. "An Introduction to the Principles of Morals and Legislation". http://oll.libertyfund.org/titles/278.

Diakses 29 Oktober 2015.
Rakyat. "Pemda Harus Punya Data Jumlah MBR Yang Perlu Bantuan Pembiayaan Perumahan". http://www. pu.go.id/berita/10622/Pemda-HarusPunya-Data-Jumlah-MBR-Yang-PerluBantuan-Pembiayaan-Perumahan. Diakses 14 Mei 2016. 